Original Research Article

\title{
Evaluation of antiulcerogenic activity of combination of Aloe vera and Aegle marmelos in indomethacin induced gastric ulcers
}

\author{
Leela Hugar ${ }^{1}$, Ramesh H. ${ }^{2 *}$
}

${ }^{1}$ Department of Pharmacology, B. M. Patil Medical College, Vijayapura, Karnataka, India ${ }^{2}$ Department of Pharmacology, Karnataka Institute of Medical Sciences, Hubli, Karnataka, India

Received: 11 February 2019

Accepted: 15 February 2019

*Correspondence to:

Dr. Ramesh H.,

Email: kimsramesh@

yahoo.co.in

Copyright: (C) the author(s), publisher and licensee Medip Academy. This is an openaccess article distributed under the terms of the Creative Commons Attribution NonCommercial License, which permits unrestricted noncommercial use, distribution, and reproduction in any medium, provided the original work is properly cited.

\begin{abstract}
Background: Most important adverse effect of NSAID is peptic ulceration. Even though $\mathrm{H} 2$ blockers and proton pump inhibitors are effective in preventing NSAID associated peptic ulceration, they are not without side effects. Hence there is a need for drugs which are effective in preventing NSAID induced peptic ulcer without producing side effects. Two plant products Aloe vera leaf extract and Aegle marmalos leaves are commonly used in Indian traditional medicine for treatment of peptic ulcers. Hence this study is undertaken to assess the antiulcerogenic potential of combination of these two drugs in comparison with ranitidine in preventing NSAID induced peptic ulcers.

Methods: 18 albino rats were divided into 3 groups of 6 rats each. Group A: received ulcerogen only. Group B: pretreated with ranitidine before exposing to ulcerogen. Group C: pretreated with combination of Aloe vera and Aegle marmelos before exposing to ulcerogen. Two doses of indomethacin were administered at an interval of $15 \mathrm{hrs}$. Animals were sacrificed $6 \mathrm{hrs}$ after the second dose of Indomethacin. Number of ulcers was noted, and ulcer index was calculated.

Results: There was significant reduction in total score, mean score and ulcer index in ranitidine pretreated group and test compound group as compared to control group. Even though the total score and ulcer index in test group were lesser as compared to standard control group, it was not statistically significant.

Conclusions: Combination of Aloe vera leaf extract and Aegle marmelos leaf extract produced very significant protection against indomethacin induced gastric ulcer.
\end{abstract}

Keywords: Aloe vera, Aegle marmelos, Gastric ulcers, Indomethacin, Ulcer index

\section{INTRODUCTION}

Non steroidal anti-inflammatory drugs (NSAID) are the most commonly used drugs in clinical practice. One of the most important adverse effect of NSAID is peptic ulceration. Hence the long-term treatment with NSAID is usually combined with antiulcer drugs. Even though $\mathrm{H} 2$ blockers and Proton pump inhibitors are very effective in preventing NSAID associated peptic ulceration, they are not without side effects. Hence there is a need for drugs which are effective in preventing NSAID induced peptic ulcer without producing side effects
Use of natural drugs in gastric ulcers is well documented. ${ }^{1}$ Two plant products Aloe vera leaf extract and Aegle marmalos leaves are commonly used in Indian traditional medicine for treatment of peptic ulcers. Aloe vera is a perennial plant with a whorl of elongated and pointed leaves. The epidermis of the leaves has a thick cuticle and beneath is a zone of chlorenchyma. The mucilaginous tissue made up of large thin-walled mesophyll cells in the center of the leaf is called Aloe vera gel and this gel is responsible for many of medicinal properties of Aloe vera reported in folk medicine. ${ }^{2}$ Active constituents of Aloe vera include barbalin, isobarbolin, and saponins 
Aegle marmelos which is commonly known as a "bael tree" belonging to the family rutaceae is the plant that chiefly grows on throughout India. Chemical constituents in this plant are flavonoids, tannins, and saponins. Aegle marmelos leaves extract found to possess, free-radical scavenging activity and radio protective effect. ${ }^{3}$ Moreover, the leaf extract is proved to be hepatoprotective and anti bacterial. ${ }^{4,5}$ The major chemical constituents of leaves extract were alkaloids like aegelenine and aegeline, coumarins and tannins. Even though both Aloe vera leaves extract and Aegle marmelos leaves extract are effective in preventing NSAID induced peptic ulcers, still $\mathrm{H} 2$ blockers and proton pump inhibitors are more efficacious than these two natural drugs. Hence this study is undertaken to assess the antiulcerogenic potential of combination of Aloe vera leaf extract and Aegle marmelos leaf extract in comparison with ranitidine in preventing NSAID induced peptic ulcers.

\section{METHODS}

\section{Animals}

Around 18 albino rats of Wistar strain of either sex weighing 150-200g were selected from central animal house of BM Patil Medical College, Vijayapura, Karnataka. The animals were kept on standard diet and allowed food and water ad libitum. The experimental protocol was approved by the institutional animal ethical committee.

\section{Materials}

\section{Drugs}

Indomethacin (Microlabs Ltd) as ulcerogenic agent. Ranitidine (JB Chemicals and Pharmaceuticals Ltd) as standard control. Combination of Aloe vera leaf extract and Aegle marmelos leaf extract as test compound. The plant specimen was identified and authenticated in the Department of Botany KCP Science College Vijayapur, Karnataka, India.

\section{Dose and duration and administration of drugs}

Indomethacin, the ulcerogenic agent was used in dose of $20 \mathrm{mg} / \mathrm{kg}$ orally. Two doses were given at an interval of 15hrs. Ranitidine, the standard control drug was used in the dose of $25 \mathrm{mg} / \mathrm{kg}$, once daily for 5 days. Combination of Aloe vera leaf extract $200 \mathrm{mg} / \mathrm{kg}$ and Aegle marmelos leaf extract $1 \mathrm{gm} / \mathrm{kg}$ was given once daily for 5 days 6,7 .

\section{Preparation of Aloe vera leaf extract}

Fresh, Aloe vera leaves of about 400-600g in weight were collected. The rind was selectively removed, and the colourless parenchyma was ground in a blender and centrifuged at $10,000 \mathrm{~g}$ to remove the fibers. The supernatant was lyophilized and stored at $4{ }^{\circ} \mathrm{C} .{ }^{8}$

\section{Preparation of Aegle marmelos leaf extract}

Aegle marmelos leaves were dried at $50^{\circ} \mathrm{C}$, powdered coarsely and extracted with $75 \%$ methanol twice by soaking in a container overnight. The extract was evaporated to dryness. Again, the extract was re suspended in distilled water and used for the animal experiments. ${ }^{9}$

\section{Procedure}

Around 18 albino rats were divided into 3 groups of 6 rats each.

- Group A (Control): Received ulcerogen only.

- Group B (Standard control): Received ranitidine once daily for 3 days and 30 minutes prior to ulcerogen on $4^{\text {th }}$ and $5^{\text {th }}$ day.

- Group C (Test compound): Received Combination of Aloe vera and Aegle marmelos once daily for 3 days and 30 minutes prior to ulcerogen on $4^{\text {th }}$ and $5^{\text {th }}$ day.

The animals in all the groups were fasted for $24 \mathrm{hrs}$ prior to the administration of ulcerogen with water ad libitum. Two doses of indomethacin were administered at an interval of $15 \mathrm{hrs}$. Animals were sacrificed $6 \mathrm{hrs}$ after the second dose of indomethacin by dislocating cervico-atlanto joint. The anterior abdominal wall was opened, and the stomach was dissected out. The dissected stomachs were opened along the greater curvature, the number of ulcers was noted and grading of ulcers was done according to the method described by Laurence and Bacharach. ${ }^{10}$

Grade (Type of gastric mucosa)

- 0 (Normal)

- 1 (Scattered hemorrhage spots)

- 2 (Hemorrhagic spots + ulcer)

- 3 (Deep hemorrhagic spots + ulcer)

- 4 (Perforation).

The ulcer index was calculated for each group by the method of Sunita and Devdas ${ }^{11}$

\section{Statistical analysis}

The results were interpreted by unpaired t test. A p value of $<0.05$ was considered as statistically significant.

\section{RESULTS}

The results were analysed by unpaired t test. There was significant reduction in total score, ulcer incidence and ulcer index in Ranitidine pretreated group and Test compound pretreated group as compared to control group $(\mathrm{p}<0.05)$. There was no significant statistical difference between ranitidine pretreated group and test compound pretreated group. Group A: In this group, the total score was 18 , mean score was 3 , ulcer incidence is $100 \%$ and ulcer index was 5. Group B: In this group there was 
significant reduction in total score (8), mean score (1.3), ulcer incidence (67\%) and ulcer index (2.6) as compared to control group $(\mathrm{p}<0.05)$.

Group C: In this group there was significant reduction in total score (6), mean score (1), ulcer incidence (50\%) and ulcer index (2) as compared to control group $(\mathrm{p}<0.01)$. Even though the total score and ulcer index were lesser as compared to standard control group, it was not statistically significant $(\mathrm{p}>0.05)$.

Table 1: Comparison of all three groups.

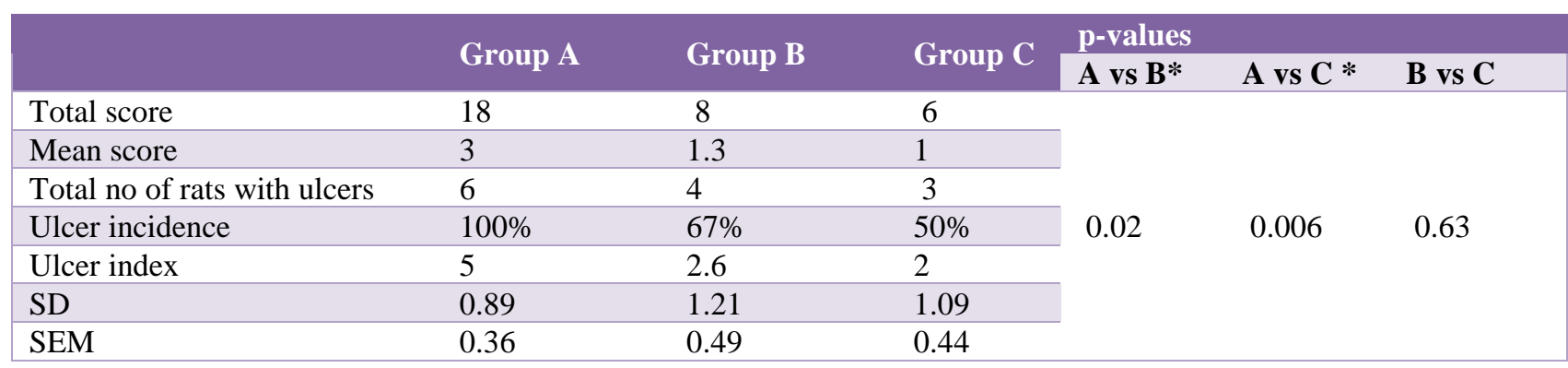

* $\mathrm{p}<0.05$-significant, SD-standard deviation, SEM-standard error of mean

\section{DISCUSSION}

Present study was undertaken to evaluate the protective effect of combination of Aloe vera and Aegle marmelos against indomethacin induced gastric mucosal damage. Normal amount of gastric acid is necessary for the development of gastric ulcers produced by NSAID. ${ }^{12}$ In the present study, the total score, ulcer incidence and ulcer index in ranitidine pretreated animals (group B) were significantly reduced as compared to control group $(\mathrm{p}<0.05)$. As the $\mathrm{H}_{2}$ blockers reduce the gastric acid secretion, they are effective in preventing the gastric mucosal damage produced by NSAID. In test compound group (group C), the total score, ulcer incidence and ulcer index were significantly reduced when compared to control group $(\mathrm{p}<0.01)$. Even though the total score and ulcer index were less as compared to ranitidine pretreated group it was not statistically significant $(\mathrm{p}>0.05)$.

So, the protection given by combination of Aloe vera and Aegle marmelos against Indomethacin induced gastric mucosal damage was nearly comparable or slightly more than that by ranitidine

In an investigation on the effect of Aloe vera by Heggers et al, it was found that it increased $\mathrm{PGE}_{2}$ levels in test group compared to controls. ${ }^{13}$ A study by Cappaso et al, found that it stimulated prostaglandin synthesis. ${ }^{14}$ In a study conducted by Yusuf S et al it was demonstrated that the Aloe vera extract has gastric acid inhibitory properties in addition to gastroprotective activity. ${ }^{15}$ Keshavarzi et al also in their study demonstrated the inhibitory effect on gastric acid secretion by Aloe vera from these studies it appears that Aloe vera has both gastric acid inhibitory effect as well as prostaglandin synthesis stimulatory effect which protects the gastric mucosa by secreting the mucus. $^{16}$
In a study by Singh $\mathrm{P}$ and Guha $\mathrm{D}$, it was concluded Aegle marmelos, significantly augment production of gastric mucus and mucin, and enhancing protective properties of the mucous barrier. ${ }^{17}$ Sharmila et al, in their study demonstrated the antisecretory and gastroprotective effect of Aegle marmelos. ${ }^{18}$ In our study the combination of Aloe vera leaf extract and Aegle marmelos leaf extract produced very significant protection against indomethacin induced gastric ulcer. This antiulcer activity may be due to gastric acid secretion inhibition as well as augmenting gastric mucus secretion as a combined effect from both the drugs.

\section{CONCLUSION}

Combination of Aloe vera leaf extract and Aegle marmelos leaf extract produced very significant protection against indomethacin induced gastric ulcer. The protection was slightly better than ranitidine. However further studies are required to elucidate exact mechanism of action.

Funding: No funding sources

Conflict of interest: None declared

Ethical approval: The study was approved by the Institutional Ethics Committee

\section{REFERENCES}

1. Goel RK, Gupta S, Shankar R, Sanyal AK. Antiulcerogenic effect of banana powder (Musa sapientum Var. paradisiaca) and its effects on mucosal resistance. J Ethano Pharmacol. 1986;18:33-44.

2. Subramanian S, Kumar DS, Arulselvan P, Senthilkumar GP, Rao UM. Evaluation of antiulcerogenic potential of Aloe vera leaf gel extract studied in experimental rats. J Pharmacol Toxicol. 2007;2(1):85-97. 
3. Rani P, Khullar N. Antimicrobial evaluation of some medicinal plants for their anti-enteric potential against multi-drug resistant Salmonella typhi. Phytother Res. 2004;18(8):670-73.

4. Mansi V. Investigation on antiulcer activity of Aegle marmelos root as experimental, biochemical and histological study. J Pharm Res. 2010;3(10):2523-8.

5. Shay H, Komarov SA, Fels SE, Meraze D, Gruenstein M, Siplet H. A simple method for the uniform production of gastric ulceration. Gastroenterol. 1945;5:43-61.

6. Borra SK, Lagisetty RK, Mallela GR. Anti-ulcer effect of Aloe vera in non-steroidal anti-inflammatory drug induced peptic ulcers in rats. Afr J Pharm Pharmacol. 2011 Oct 29;5(16):1867-71.

7. Ilavarasan JR, Monideen S, Vijayalakshmi M. Antiulcer activity of Aegle marmelos. Ancient Science of Life. 2002;21(4):23-6.

8. Yagi A, Hine N, Asai M, Nakazawa M, Tateyama Y, Okamura N, et al. Tetrahydroanthracene glucosides in callus tissue from Aloe barbadensis leaves. Phytochemistry. 1998 Apr 1;47(7):1267-70.

9. Shenoy AM, Singh R, Samuel RM, Yedle R, Shabraya AR. Evaluation of anti-ulcer activity of Aegle marmelos leaves extract. IJPSR. 2012 May 1;3(05):1498-501.

10. Laurence DR, Bacharach AL, editors. Evaluation of drug activities: pharmacometrics. 1st ed. New York: Academic press; 1964:510.

11. Sunita J, Devdas S. Modification of duodenal ulcer by calcium channel blockers in rats. Ind J Pharmacol. 1996;28:167-70.

12. Robert A. Cytoprotection by prostaglandins. Gastroenterology. 1979 Oct 1;77(4):761-7.
13. Heggers JP, Loy GL, Robson MC, Del Beccaro EJ. Histological demonstration of prostaglandins and thromboxanes in burned tissue. J Surg Res. 1980 Feb $1 ; 28(2): 110-7$.

14. Capasso F, Mascolo N, Autore G, Duraccio MR. Effect of indomethacin on aloin and 1, 8 dioxianthraquinone-induced production of prostaglandins in rat isolated colon. Prostaglandins. 1983 Oct 1;26(4):557-62.

15. Yusuf S, Agunu A, Diana M. The effect of Aloe vera A. Berger (Liliaceae) on gastric acid secretion and acute gastric mucosal injury in rats. J Ethnopharmacol. 2004 Jul 1;93(1):33-7.

16. Keshavarzi Z, Rezapour TM, Vatanchian M, Hesari MZ, Haghighi HN, Izanlu M, et al. The effects of aqueous extract of Aloe vera leaves on the gastric acid secretion and brain and intestinal water content following acetic acid-induced gastric ulcer in male rats. Avicenna J Phytomed. 2014 Mar;4(2):137.

17. Singh P, Guha D. Aegle marmelos enhances gastric mucosal protection: relevance for NSAIDS-induced gastric mucosal injury. Al Ameen $J$ Med Sci. 2012;5(3):243-255.

18. Sharmila S, Vasundara Devi PA, Divyapriya S. Gastroprotective effect of aqueous extract of Aegle marmelos unripe fruit in albino rats. Int $\mathbf{J}$ Med Pharma Sci. 2013;3(1):21-6.

Cite this article as: Hugar L, Ramesh $\mathrm{H}$. Evaluation of antiulcerogenic activity of combination of Aloe vera and Aegle marmelos in indomethacin induced gastric ulcers. Int J Basic Clin Pharmacol 2019;8:453-6. 